\title{
Botulinum Toxin A Induced Protective Ptosis
}

\author{
G. G. W. ADAMS, C. M. KIRKNESS, J. P. LEE \\ London
}

\begin{abstract}
Summary
Botulinum Toxin A injected into the levator palpebrae superioris produces a flaccid ptosis of the upper lid and provides a safe and effective protection for the cornea to aid healing in indolent ulceration or as prophylaxis when there is fifth or seventh cranial nerve damage. Fifteen patients have received this treatment. Levator paresis, producing ptosis for a mean of 2-3 weeks and recovering in a mean of 8.1 weeks was successfully produced in all patients and complete corneal healing was produced in $80 \%$ of patients. The major side effect was weakness of the superior rectus muscle which occurred in $80 \%$ of cases and lasted a mean of 6 weeks.
\end{abstract}

Surgical tarsorraphy has been used for many years to provide protection to vulnerable corneas and as a means to hasten healing in cases where there is indolent ulceration. The presence of an extensive central tarsorraphy may impede instillation of topical medication, hinder examination of the globe and ocular

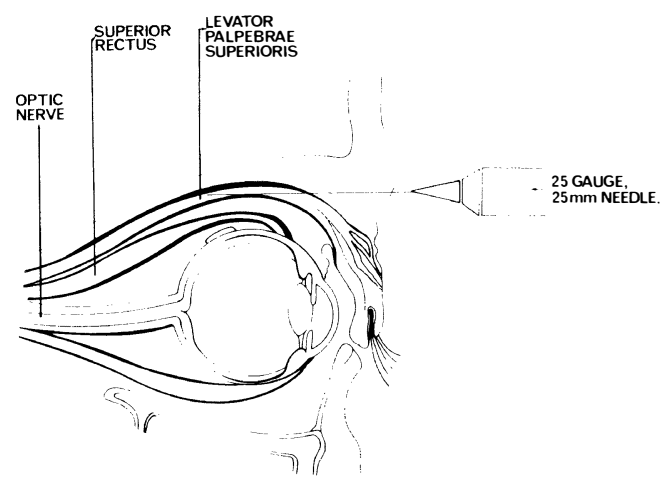

Fig. 1. The 25 gauge, $25 \mathrm{~mm}$ needle is inserted just under the orbital margin passing backwards parallel to the roof of the orbit and the toxin is injected into the levator muscle. surface and when the tarsorraphy is opened there may be serious distortion of the lid margins resulting in further corneal damage. Many patients find the appearance disturbing and some find it uncomfortable. In other cases, bandage contact lenses may be an acceptable form of therapy but often their use may be contra-indicated, e.g. by severe blepharitis. Taping the lids shut may be a short term solution as may the use of the tissue adhesive to stick the lid margins together, but in most cases such devices are not tolerated for long periods because of skin irritation and they may provide inadequate corneal cover. Moreover, taping requires some degree of skill on the part of the patient if it is to be applied safely and effectively.

Botulinum toxin $\mathrm{A}$ is one of the eight toxins produced by Clostridium botulinum. The toxin is internalised into the presynaptic nerve. It then blocks acetylcholine release producing functional denervation of the muscle fibres for several weeks. New myoneural junctions are formed over 6 to 8 weeks

From Department of Clinical Ophthalmology, Institute of Ophthalmology, Moorfields Eye Hospital.

Correspondence to: C. M. Kirkness, FRCS, Department of Clinical Ophthalmology, Institute of Ophthalmology, Moorfields Eye Hospital, City Road, London EC1 2PD.

Presented at the Annual Congress of the Opthalmological Society of the United Kingdom, April, 1987. 
and muscle activity returns to normal. The toxin does not induce scar tissue formation. ${ }^{1}$

This property has been used clinically since 1978 to produce temporary paresis of extraocular muscles in the management of strabismus and of the orbicularis oculi muscles for essential blepharospasm..$^{2.3 .4 .5}$ It was noted, in many of the patients undergoing this treatment, that a temporary ptosis often resulted due to the infiltration of the levator palpebrae superioris muscle (LPS) with toxin. Recovery of muscle function is dependent on growth of a new motor end plate,$^{6}$ a process which may be prolonged in the fast or twitch fibres found in the LPS7.

It was thought that if a ptosis could be deliberately produced by this method, it might have the same beneficial effect of producing healing in indolent corneal ulcers or protection to exposed corneas without the subsequent problems of surgical tarsorraphy.

A prospective trial using Botulinum Toxin A induced protective ptosis (BTPP) in 15 patients is reported.

\section{Material and Methods}

Patients who would otherwise have undergone a central or total tarsorraphy were offered BTPP. Prior to treatment, examination included measurement of visual acuity, levator function, full orthoptic assessment, full documentation of the underlying condition and photography of the anterior segment and face. Patients were seen, at most, one week after the initial injection and then at regular intervals when a similar examination was

Table I. Summary of the clinical details and results.

\begin{tabular}{|c|c|c|c|c|c|c|}
\hline Patient & Indication & $\begin{array}{l}\text { Initial } \\
\text { acuity }\end{array}$ & $\begin{array}{l}\text { Number of } \\
\text { injections \& } \\
\text { dose } \times 10^{-5} \mu\end{array}$ & $\begin{array}{l}\text { Time to } \\
\text { ptosis }\end{array}$ & $\begin{array}{l}\text { Ptosis complete } \\
\text { /incomplete }\end{array}$ & $\begin{array}{l}\text { Duration max } \\
\text { ptosis }\end{array}$ \\
\hline 1 & ulcer, npk $2 \mathrm{Y}$ hzo & $6 / 24$ & $3 \times 6.25$ & 4 days & complete & 2 weeks \\
\hline 2 & ulcer, hsk atopy & $P$ of $L$ & $1 \times 6.25$ & $30 \mathrm{hrs}$ & complete & 3 weeks \\
\hline 3 & ulcer, hsk & $\mathrm{CF}$ & $4 \times 6.25$ & 3 days & $\begin{array}{l}\text { incomplete } \\
\text { ipf }=2.5 \mathrm{~mm}\end{array}$ & 2 weeks \\
\hline 4 & ulcer, hsk, pk & $1 / 60$ & $3 \times 6.25$ & 4 days & incomplete & 3 weeks \\
\hline 5 & $\begin{array}{l}\text { ulcer, bk, csg, lid } \\
\text { notch }\end{array}$ & $\mathrm{HM}$ & $\begin{array}{l}3 \times 6.25 \\
1 \times 12.5\end{array}$ & 7 days & $\begin{array}{l}\text { complete bar } \\
\text { medial lid notch gap } \\
1.5 \mathrm{~mm} \text { across }\end{array}$ & 2 weeks \\
\hline 6 & LMN VII & $6 / 18$ & $\begin{array}{l}1 \times 6.25 \\
2 \times 12.5\end{array}$ & 10 days & $\begin{array}{l}\text { incomplete } \\
\text { ipf }=1 \mathrm{~mm}\end{array}$ & 2 weeks \\
\hline 7 & $\begin{array}{l}\text { ulcer, cc, } \\
\text { Descemetocoele }\end{array}$ & $\mathrm{HM}$ & $\begin{array}{l}1 \times 6.25 \\
1 \times 12.5\end{array}$ & 3 days & complete & 2 weeks \\
\hline 8 & $\begin{array}{l}\text { ulcer, pk, Stevens- } \\
\text { Johnston }\end{array}$ & $\mathrm{CF}$ & $\begin{array}{l}1 \times 6.25 \\
1 \times 12.5\end{array}$ & 5 days & complete & 1 week \\
\hline 9 & $\begin{array}{l}\text { ulcer, npk, } 2 \text { Y } \\
\text { section of } V \text { lateral } \\
\text { tarsorraphy }\end{array}$ & $1 / 60$ & $1 \times 12.5$ & 7 days & complete & 4 weeks \\
\hline 10 & ulcer, pk, rheumatoid & $6 / 60$ & $2 \times 6.25$ & 5 days & $\begin{array}{l}\text { incomplete } \\
\text { ipf }=1 \mathrm{~mm}\end{array}$ & 1 week \\
\hline 11 & ulcer, alkali injury & $6 / 60$ & $2 \times 6.25$ & 4 days & $\begin{array}{l}\text { complete after } 2 \text { nd } \\
\text { injection }\end{array}$ & 3 weeks \\
\hline 12 & ulcer, hsk & $\mathrm{CF}$ & $1 \times 12.5$ & 4 days & $\begin{array}{l}\text { incomplete } \\
\text { ippf }=2 \mathrm{~mm}\end{array}$ & 2 weeks \\
\hline 13 & $\begin{array}{l}\text { LMN VII, postop } \\
\text { acoustic neuroma } \\
\text { prohylaxis }\end{array}$ & $6 / 5$ & $\begin{array}{l}1 \times 12.5 \\
1 \times 6.25\end{array}$ & 10 days & complete & 10 days \\
\hline 14 & ulcer, npk 2 Y RTA & $4 / 60$ & $1 \times 12.5$ & 4 days & $\begin{array}{l}\text { incomplete } \\
\text { ipf }=1.5 \mathrm{~mm}\end{array}$ & 2 weeks \\
\hline 15 & $\begin{array}{l}\text { sk, npk, V ganglion } \\
\text { block }\end{array}$ & CF & 1.6 .25 & 3 days & complete & 3 weeks \\
\hline
\end{tabular}

Summary of the details of the patients:

Recovery times for levator function and lid position are from the time of the last injection.

*1 this patient subsequently underwent tarsorraphy and eye movements could not fully be tested.

*2 this patient's palpebral fissure recovered to pre-injection levels 3 weeks after injection but levator function was still

reduced by $1 \mathrm{~mm}$. At this time further lid surgery was undertaken.

*3 this patient's prophylactic treatment continues. 
carried out. No more than four injections were administered. Botulinum Toxin A was supplied by Prof J. Melling of the Vaccine Research and Production Laboratory PHLS CAMR, Porton Down. The toxin is sterilised by filtration, dissolved in saline and human albumin and freeze dried. Vials containing $0.05 \mu \mathrm{g}$ of toxin-haemagglutin complex were reconstituted immediately before use with preservative-free isotonic saline. The first eleven patients received initial injections of $6.25 \times 10^{-5} \mu \mathrm{g}$ and the later four patients were given doses of $12.5 \times 10^{-5} \mu \mathrm{g}$ equivalent to a volume of $0.2 \mathrm{ml}$.

The toxin was injected using a 25 gauge needle just beneath the superior orbital margin to a depth of $25 \mathrm{~mm}$. (Fig. 1) Electromyographic control was not necessary. No anaesthesia was required.

The effect was not instantaneous, taking some days to develop and during that time it was often necessary to protect the cornea with lid taping and to maintain current medical therapy.

Further injections to a maximum of four, in total, were given if a sufficient degree of ptosis did not develop in a week, if the effect began to wear off before full healing had taken place or if further protection was required.

\section{Results}

Fifteen patients were treated with BTPP. (Table I). The time taken for maximum ptosis to develop varied from 30 hours to 10 days (mean 3 days) following injection. Ptosis was complete in 8 patients and complete corneal coverage was produced in a further 3 patients after injection, but a subsequent injection was necessary in 4 of the cases. (Fig. 2) Full ptosis

\begin{tabular}{|c|c|c|c|c|c|}
\hline Epithelialisation & $\begin{array}{l}\text { Superior rectus } \\
\text { underaction \& } \\
\text { duration }\end{array}$ & $\begin{array}{l}\text { Other } \\
\text { complications }\end{array}$ & $\begin{array}{l}\text { Time to } \\
\text { recovery full } \\
\text { levator function }\end{array}$ & $\begin{array}{l}\text { Time to } \\
\text { Recovery } \\
\text { lid position }\end{array}$ & $\begin{array}{l}\text { Final } \\
\text { acuity }\end{array}$ \\
\hline complete & $\stackrel{+}{5 \text { months }}$ & Diplopia & 5 months & $\begin{array}{l}\text { nyr } \\
\text { at } 5 \text { months }\end{array}$ & $6 / 9$ \\
\hline complete & ${ }_{3}^{+}$months & - & 3 months & 2 months & $6 / 9$ \\
\hline complete & $\stackrel{+}{3 \text { months }}$ & bruising & $\begin{array}{l}\text { nyr } \\
7 \text { months }\end{array}$ & 5 months & $6 / 18$ \\
\hline complete & ${ }_{1}^{+}$month & - & 6 weeks & 2 months & $2 / 60$ \\
\hline $\begin{array}{l}\text { complete under } \\
\text { covered area }\end{array}$ & $\begin{array}{l}+ \\
{ }^{*} 1\end{array}$ & suppurative keratitis & 6 weeks & ${ }^{* 1} 1$ & $\mathrm{HM}$ \\
\hline maintained & $\begin{array}{l}+ \\
3 \text { months }\end{array}$ & diplopia, prisms used & 10 weeks & $\begin{array}{l}\text { nyr } \\
\text { at } 14 \text { weeks }\end{array}$ & $6 / 18$ \\
\hline complete & $\begin{array}{l}+ \\
3 \text { weeks }\end{array}$ & $\begin{array}{l}\text { progression of disease, } \\
\text { pk for perforation }\end{array}$ & 3 months & 3 months & $1 / 60$ \\
\hline partial & $\stackrel{+}{3 \text { weeks }}$ & $\begin{array}{l}\text { progression of disease, } \\
\text { repeat pk }\end{array}$ & $* 2$ & ${ }^{*} 2$ & $3 / 60$ \\
\hline complete & - & - & $\begin{array}{l}\text { nyr } \\
2 \text { months }\end{array}$ & $\begin{array}{l}\text { nyr } \\
\text { at } 2 \text { months }\end{array}$ & $6 / 18$ \\
\hline incomplete & - & $\begin{array}{l}\text { progression of } \\
\text { disease, repeat pk }\end{array}$ & $\begin{array}{l}\text { no measurable } \\
\text { change }\end{array}$ & 3 weeks & $6 / 24$ \\
\hline complete & ${ }_{1}^{+}$month & - & 6 weeks & 6 weeks & $1 / 60$ \\
\hline complete & - & - & 4 weeks & 4 weeks & $1 / 60$ \\
\hline maintained & ${ }_{3}^{+}$weeks & - & $\begin{array}{l}\text { nyr } \\
* 3\end{array}$ & $\begin{array}{l}\text { nyr } \\
* 3\end{array}$ & $6 / 4$ \\
\hline complete & $\begin{array}{l}+ \\
{ }^{*} 4\end{array}$ & - & 6 weeks & 6 weeks & $6 / 36$ \\
\hline complete & + & - & $\begin{array}{l}\text { nyr } \\
1 \text { month }\end{array}$ & $\begin{array}{l}\text { nyr } \\
\text { at } 1 \text { month }\end{array}$ & $\mathrm{CF}$ \\
\hline
\end{tabular}

*4 this patient had a partial IIIrd nerve palsy prior to BTPP but his superior rectus underaction did not increase following injection.

Abbreviations. Bk-bullous keratopathy; cc-cicatrising conjunctivitis; csg-chronic simple glaucoma; hsk-herpes simplex keratitis; hzo-herpes zoster ophthalmicus; ipf-interpalpebral fissure, maximum width; LMN-lower motor neurone lesion of VIIth cranial nerve; npk-neuroparalytic keratitis; nyr-not yet recovered; pk-penetrating keratoplasty; sk-suppurative keratitis; 2 Y secondary; + present; - absent. 

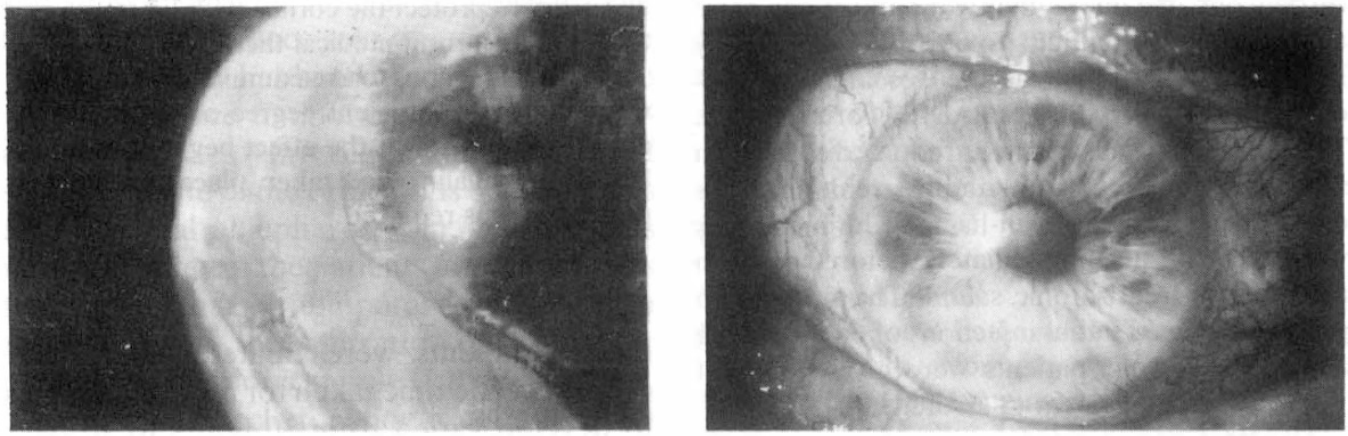

Fig. 2. Cornea of patient no 2 (A) before BTPP, stained with fluorescein and $(B) 10$ days after injection showing complete healing of the epithelium.

lasted from 7 days to 5 weeks (mean 2.5 weeks) before recovery began. Recovery took place up to a maximum time of 7 months (mean 8.1 weeks) but the follow-up period of 3 patients is too short for full recovery to have taken place. In 10 cases, including the 4 mentioned above, further injections were given because healing was not complete or because continuing protection was necessary. (Fig. 3.)

In the 13 cases where the lid closure was indicated because of a corneal epithelial defect, complete healing occurred in 10 cases and almost complete healing in one further case. Progression of the underlying condition, after an initially successful response (including full re-epithelialisation of the defect in 2 cases), was seen in 4 cases, despite adequate corneal coverage. These cases included; a patient with Stevens-Johnson syndrome and a penetrating keratoplasty who had recurrent corneal epithelial defects with melting, a patient with uncontrolled sclerokeratitis and peripheral corneal melt and corneal graft and
2 patients with advanced cicatricial conjunctivitis. One of these latter two patients represented the only failure of the procedure to produce complete closure of the lids despite complete covering of the epithelial defect. This was due to a notch at the medial aspect of the upper lid which led to exposure of the globe and subsequent ulceration which developed after the original defect had healed. A medial tarsorraphy was later performed which, interestingly, led to periorbital cellulitis from a suture abscess. The final patient with cicatrising conjunctivitis developed a suppurative keratitis after the epithelial defect had healed.

Other complications did occur but in most cases were not serious and were self resolving. Preseptal haemorrhage occurred in one case. This had the beneficial effect of producing immediate closure of the lid! The most common complication found was underactivity of the ipsilateral superior rectus muscle. This was not unexpected due to the proximity of
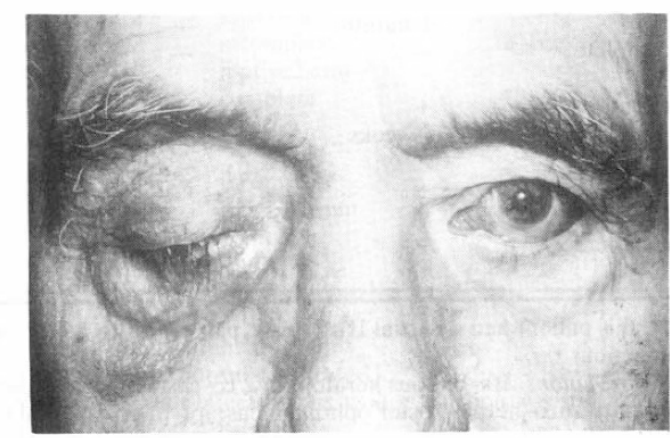

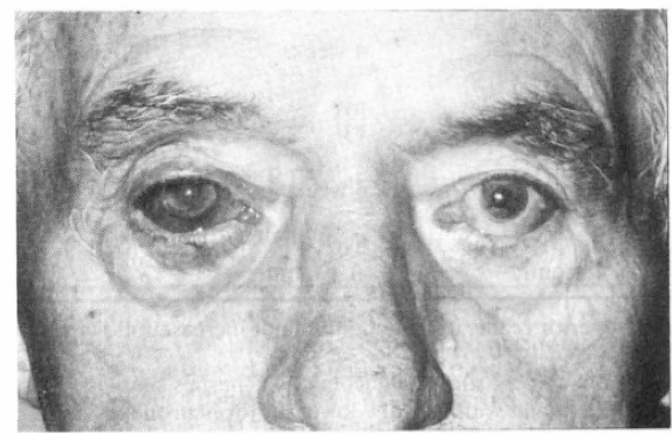

Fig. 3. Patient $3(A)$ before injection and $(B) 2$ weeks after injection. $N B$ this is an incomplete ptosis. 
the superior rectus and the LPS. Temporary underactivity was observed in 12 cases, but in only 2 cases did the patient appreciate vertical diplopia as the lid began to open. Prisms were required for 3 months for relief of this symptom by one patient and in the other patient full ocular motility was achieved after 5 months. Other induced muscle weakness was not found. In all cases the induced superior rectus weakness recovered fully in a mean of 6 weeks.

\section{Discussion}

Healing of epithelial defects in the cornea in the presence of neuroparalytic keratitis or other conditions where there are severe ocular surface abnormalities is often very difficult to achieve. None of the standard techniques currently used to promote healing is without risk to the eye or the lid margins. Botulinum toxin A induced ptosis is an effective means of producing full corneal coverage and epithelial healing ensues rapidly. The flaccid paralysis of the LPS may have additional benefit in reducing the amount of lid movement without disturbing tear film spreading since the action of orbicularis oculi is unimpeded. The technique is simple and does not damage lid margin structures but it should be used with care when any scarring is suspected in the region of the LPS because adequate closure may not be produced. Similarly when there is likely to be inadequate closure due to cicatricial lid deformity, additional care and supervision may be required, but providing full closure can be achieved cicatricial disease need not be an absolute contraindication to BTPP. Since the flaccid lids may be easily opened, full examination is not hindered and any necessary medications may be instilled without difficulty and without the need to use preservative free solutions which would be preferable with bandage lenses.

As in the use of bandage contact lenses, scrupulous attention must be paid to the cleanliness of the lid margins since there may be a t $t$.ldency for pooling of the tear film which may predispose to infection. The disappointing results in patients with advanced cicatrising cojunctivitis may reflect the poor defences on the ocular surface in these cases, but such patients are always at very high risk of developing acute exacerbations of their conditions.

Precise comparison with other techniques from the point of view of healing rates is difficult because of the varied nature of the underlying pathology and the small numbers involved, nevertheless epithelial defects appeared to heal very quickly with BTPP often where other techniques had failed.

The only associated abnormality of ocular motility was a temporary weakness of the superior rectus muscle which recovered completely in all cases. Scott ${ }^{2}$ noted in the ptosis developing in association with superior rectus injection of Botulinum toxin, that the ptosis may last 6 months or more following injection. Where follow-up is long enough, our figures suggest that levator function recovers to pre-injection levels within six months. Clearly BTPP is not suitable for permanent closure of the lids but it may provide valuable protection temporarily in cases before a decision can reasonably be made that a permanent tarsorraphy is indicated $e g$ in cases of acoustic neuromata where there is fifth and seventh nerve damage at the time of surgery. The prophylactic use of BTPP may avoid tarsorraphy in many such cases.

Perhaps, surprisingly, patient acceptability was very high. All those who had practised taping said they preferred the BTPP. None was concerned by their cosmetic appearance.

The mechanism of action of corneal coverage leading to healing of defects in the corneal epithelium remains to be explained fully. It is thought that this is due to lack of movement because of the flaccid paralysis, but some relief of mechanical effect on the ocular surfaces might be expected. Whether reduction of lid motility aids this can only be speculative in the absence of biopsy material. Impression cytology may provide interesting data from these cases in whom biopsy is clearly contraindicated.

The new technique of Botulinum Toxin A induced protective ptosis may be useful in providing corneal protection or for promoting healing of corneal epithelial defects in longstanding breakdown.

We are most appreciative of the help we received from 
the Department of Orthoptics, particularly Miss Sue Watkins and Miss Bernadette McCarry for their meticulous documentation of our cases.

\section{References}

' Guyton AC and MacDonald MA: The physiology of Botulinum Toxin. Arch Neurol Psychiat 1947, 87: $587-92$.

${ }^{2}$ Scott AB: Personal Communication.

${ }^{3}$ Elston JS: The use of Botulinum Toxin $\mathrm{A}$ in the treatment of strabismus. Trans Ophthalmol Soc UK 1984, 104: 208-10.

${ }^{4}$ Fruch BR, Felt DP, Wojno TH, Musch DC: Treat- ment of blepharospasm with Botulinum Toxin. Arch Ophthalmol 1984, 102: 1464-8.

${ }^{5}$ Elston JD and Ross Russel RW: Effect of treatment with Botulinum Toxin on neurogenic blepharospasm. Br Med J 1985, 290: 1857-9.

${ }^{6}$ Duchen LW: An electron microscopic study of the changes induced by Botulinum Toxin in the motor end plates of slow and fast skeletal muscles of the mouse. J Neurol Sci 1971, 14: 47-60.

${ }^{7}$ Duchen LW: Changes in the electron microscopic structure of slow and fast skeletal muscle fibres in the mouse after the local injection of Botulinum Toxin. J Neurol Sci 1971, 14: 60-74. 